\title{
Pengaruh Waktu Sonikasi terhadap Konduktivitas Listrik Zeolit Berbahan Abu Dasar Batubara Menggunakan Metode Peleburan Alkali Hidrotermal
}

\author{
Nita Kurnia Sari*, Afdhal Muttaqin \\ Jurusan Fisika FMIPA Universitas Andalas \\ Kampus Unand, Limau Manis, Padang 25163 \\ e-mail : kurnianital@gmail.com
}

\begin{abstract}
ABSTRAK
Pembuatan zeolit sintetis berbahan abu dasar batubara menggunakan metode peleburan alkali hidrotermal telah dilakukan dengan pemberian sonikasi. Sebelum disintesis, kandungan abu dasar batubara diuji dengan XRF. Hasil XRF menunjukkan bahwa abu dasar yang digunakan memiliki kandungan $\mathrm{SiO}_{2}$ sebanyak 57,236\% dan $\mathrm{Al} 2 \mathrm{O} 3$ sebanyak 33,172\%. Abu dasar dan $\mathrm{NaOH}$ dilebur dengan perbandingan 1:1,2 g. Sampel yang telah dilebur, dilarutkan dengan larutan $\mathrm{NaAlO}_{2}$, kemudian diberikan pengaruh sonikasi sebelum proses kristalisasi zeolit (hidrotermal). Variasi waktu sonikasi diberikan pada 4 sampel adalah 0,$5 ; 1 ; 1,5$ dan 2 jam serta 1 sampel tanpa sonikasi sebagai perbandingan. Sampel hasil sintesis dicuci dengan aquades hingga mencapai pH 9-10. Karakterisasi sampel yang dilakukan meliputi karakterisasi morfologi permukaan menggunakan SEM dan pengukuran konduktivitas listrik menggunakan LCR-meter. Hasil karakterisasi SEM menunjukkan sampel dengan pemberian ultrasonik memiliki morfologi permukaan yang lebih seragam daripada sampel tanpa pemberian sonikasi. Nilai konduktivitas listrik yang dihasilkan berkisar dari $0,05206 \times 10^{-6}-2,1188 \times 10^{-6} \mathrm{~S} / \mathrm{cm}$ dan berada pada rentang bahan semikonduktor. Zeolit dengan pemberian sonikasi selama 1,5 jam mempunyai konduktivitas listrik tertinggi dibandingkan dengan sampel lain.

Kata Kunci : sonikasi, sodalit, philipsite, gobbinsite, konduktivitas listrik zeolit
\end{abstract}

\section{ABSTRACT}

Synthesis of zeolites from coal bottom ash using hydrothermal alkali fusion method had been conducted with provision of sonication. XRF characterization of bottom ash indicates that it contains $57.236 \% \mathrm{SiO}_{2}$ and $33.172 \% \mathrm{Al}_{2} \mathrm{O}_{3}$. Bottom ash was melted with $\mathrm{NaOH}$ at ratio of $1: 1.2 \mathrm{~g}$. That sample was dissolved with $\mathrm{NaAlO}_{2}$ solution and then sonicated prior to zeolite crystallization process (hydrothermal). Sonication time for 4 samples were 0.5; $1 ; 1.5$ and 2 hours and 1 sample without ultrasound as comparison. The synthesized samples were washed with distilled water to reach pH of 9-10. The morphology of zeolite surface was characterized using SEM and the conductivity measurement using LCR - meter. The result of SEM indicates that samples with provision of sonication have more uniform surface morphology than sample without provision of sonication. The conductivity values ranges from $0.05206 x$ $10^{-6}-2.1188 \times 10^{-6} \mathrm{~S} / \mathrm{cm}$ that means in the range of semiconductor materials. The highest conductivity is zeolite with sonication for 1.5 hours sonication.

Keywords: sonication, sodalite, philipsite, gobbinsite, conductivity zeolite

\section{PENDAHULUAN}

Zeolit merupakan senyawa anorganik yang terdiri atas alumina silika terhidrasi dengan saluran dan rongga-rongga berisi ion-ion logam, biasanya logam golongan alkali dan molekul air yang bergerak bebas. Zeolit tergolong ke dalam material nanopori dengan ukuran pori 0,3$0,9 \mathrm{~nm}$ (Hamdan, 1992). Zeolit secara alamiah dapat terbentuk di alam yang disebut juga dengan zeolit alam. Selain zeolit alam, zeolit juga bisa disintesis dari berbagai bahan yang mengandung alumina dan silika.

Limbah pembakaran batubara yaitu abu layang dan abu dasar merupakan salah satu bahan yang dapat digunakan sebagai material dasar zeolit, alumina dan silika. PLTU Ombilin, Sawahlunto, Sumatera Barat sebagai salah satu penghasil limbah batubara memiliki kandungan alumina dan silika yaitu 26,85\% $\left(\mathrm{AlO}_{2}\right)$ dan $51,8 \%\left(\mathrm{SiO}_{2}\right)$ untuk abu layang (Fatiha, 2013) dan abu dasar sebesar 35,618\% $\left(\mathrm{AlO}_{2}\right)$ dan 57,48\% $\left(\mathrm{SiO}_{2}\right)($ Oktaviani, 2015).

Pembuatan zeolit sintetis berkembang seiring dengan pemanfaatan zeolit pada berbagai aplikasi seperti : katalis, penukar ion, absorben, dan penyaring molekul. Saat ini terdapat lebih dari 100 jenis zeolit yang telah dihasilkan melalui berbagai proses dan bahan dasar (Audy, 2008). Perbedaan metode sangat berpengaruh pada sintesis zeolit yang dihasilkan seperti 
sintesis zeolit dari abu dasar yang dilakukan oleh Waleza (2015) menggunakan metode refluks menghasilkan zeolit Na-X dan Na-P. Nikmah (2008) melakukan sintesis zeolit dari abu dasar dengan metode hidrotermal dan menghasilkan zeolit A. Lestari (2015) mensintesis zeolit juga berbahan abu dasar dengan metode alkali hidrotermal menggunakan air laut sebagai media kristalisasi memperoleh zeolit Na-X. Sriwahyuni (2015) yang juga mensintesis zeolit menggunakan metode peleburan alkali hidrotermal dengan menambahkan larutan natrium aluminat $\left(\mathrm{NaAlO}_{2}\right)$ dengan hasil berupa zeolit A serta unnamed zeolit.

Metode hidrotermal langsung memiliki kelemahan diantaranya waktu hidrotermal yang dibutuhkan untuk kristalisasi lebih lama dan tingkat kemurnian zeolit yang masih rendah. Pada metode peleburan alkali hidrotermal, dengan menambahkan peleburan alkali pada proses hidrotermal dapat meningkatkan proses pembentukan zeolit dan zeolit yang dihasilkan memiliki kristalinitas tinggi serta waktu kristalisasi yang lebih singkat. Namun demikian, dari penelitian yang telah dilakukan oleh Sriwahyuni (2015), masih ditemukan fase amorf yang masih mungkin untuk dirubah lagi menjadi zeolit.

Pada tahun 2010, Azizi memberikan sonikasi selama satu jam pada proses pembuatan zeolit. Modifikasi metode hidrotermal ini ternyata menghasilkan kristalinitas tinggi saat diberikan pengaruh ultrasonik selama satu jam. Hasil ini diperkuat oleh Belviso dkk. (2011) yang membandingkan pengaruh ultrasonik pada proses pembuatan zeolit berbahan dasar abu layang. Belviso mendapatkan bahwa pemberian ultrasonik selama satu jam membuat kristalisasi zeolit telah terjadi lebih cepat (pada suhu $25^{\circ} \mathrm{C}$ ) dibandingkan dengan perlakuan hidrotermal tanpa ultrasonik (pada suhu $45^{\circ} \mathrm{C}$ ).

Penggunaan ultrasonik pada proses hidrotermal ternyata dapat mengubah fase amorf yang terdapat pada saat sintesis zeolit dan menjadikan waktu reaksi lebih cepat dibandingkan dengan metode hidrotermal sehingga menurunkan temperatur reaksi. Hal ini dikarenakan gelombang ultrasonik dapat mengontrol proses nukleasi sehingga mampu meningkatkan laju pertumbuhan kristal dan meningkatkan keseragaman ukuran partikel (Suslick, 1994).

Pemanfaatan zeolit sebagai pendukung piranti elektronika mulai dikembangkan sebagai sumber material semikonduktor, material sensor dan superkapasitor. Konduktivitas dan kapasitansi zeolit merupakan kunci pengoperasian zeolit sebgai material sensor, perangkat elektronik dan optoelektronik. Keunikan sifat listrik zeolit sebagai material nanopori sangat menjanjikan untuk dikembangkan pada berbagai aplikasi. Sriwahyuni (2015) memperoleh bahwa semakin tinggi kristalinitas zeolit semakin tinggi pula konduktivitas listrik zeolit semakin tinggi. Pada pengukuran konduktivitas listrik zeolit Na-Y, konduktivitas listrik zeolit meningkat seiring dengan peningkatan frekuensi (Ertugrul dan Alime, 2007).

Pada penelitian ini dilakukan pembuatan zeolit sintetis berbahan abu dasar batubara menggunakan metode peleburan alkali hidrotermal dengan pemberian variasi waktu sonikasi selama 0,$5 ; 1 ; 1,5$ dan 2 jam. Tujuan penelitian ini adalah melihat pengaruh variasi waktu sonikasi terhadap zeolit yang terbentuk dan melihat bagaimana nilai konduktivitas listrik yang dihasilkan.

\section{METODE}

Pembuatan zeolit sintetis mengacu pada penelitian yang dilakukan oleh Sriwahyuni (2015). Abu dasar diambil dari PLTU Ombilin Sawahlunto, Sumatera Barat. Abu dasar tersebut terlebih dahulu dikeringkan, dihaluskan dan diayak dengan ayakan 200 mesh untuk mendapatkan ukuran yang lebih seragam. Untuk lebih memastikan tidak terdapatnya air pada abu dasar, abu dasar dipanaskan di dalam oven pada suhu $105{ }^{\circ} \mathrm{C}$ lalu didinginkan dalam desikator. Pada proses pembuatan zeolit, abu dasar dan $\mathrm{NaOH}$ dicampur dengan perbandingan 1:1,2 g. Pencampuran dibuat untuk 5 buah sampel yang akan diberi perlakukan berbeda. Sampel ini kemudian dilebur dengan cara dipanaskan di dalam furnace pada suhu $550{ }^{\circ} \mathrm{C}$ selama satu jam. Setelah dipanaskan, sampel dikeluarkan dari furnace, didinginkan dan kemudian dihaluskan. Masing-masing sampel dilarutkan dengan $250 \mathrm{ml}$ aquabidestilat.

Sampel diaduk dengan menggunakan magnetic stirrer selama 1 jam. Setelah diaduk, sampel dimasukkan ke dalam botol polietilen dan di aging selama 2 jam pada temperatur 30 ${ }^{\circ} \mathrm{C}$, lalu disaring dengan menggunakan kertas saring, dan diambil ekstraknya. Ekstrak sampel 
yang hasil penyaringan kemudian dilarutkan dalam $50 \mathrm{ml}$ larutan $\mathrm{NaAlO}_{2}$ yang telah disiapkan terlebih dahulu. Sampel kemudian diaduk menggunakan magnetic stirrer selama satu jam.

Perlakuan selanjutnya adalah pemberian variasi sonikasi pada sampel yang telah di campur dengan larutan $\mathrm{NaAlO}_{2}$. Sampel dibagi ke dalam lima kelompok perlakuan, 1 sampel tanpa pengaruh ultrasonik (STS), dan 4 sampel dengan pengaruh ultrasonik $(240 \mathrm{~W}, 42 \mathrm{kHz})$ dengan variasi waktu 0,5 jam (SS 0,5 jam), 1 jam (SS 1 jam), 1,5 jam (SS 1,5 jam) dan 2 jam (SS 2 jam). Setelah mendapatkan perlakuan sonikasi sesuai dengan variasi yang diinginkan, sampel kemudian dimasukkan ke dalam reaktor hidrotermal (Teflon Autoclave) kemudian dimasukkan ke dalam oven dengan pengaturan temperatur $100{ }^{\circ} \mathrm{C}$ (selama $12 \mathrm{jam}$ ). Setelah di oven, sampel dipisahkan dari filtratnya, lalu dicuci dengan aquades hingga mendapatkan $\mathrm{pH}$ 910. Setelah diperoleh $\mathrm{pH}$ yang diinginkan, sampel kemudian dikeringkan pada temperatur 105 ${ }^{\circ} \mathrm{C}$ selama 24 jam. Sehingga diperoleh zeolit aktif dalam bentuk serbuk.

\section{HASIL DAN DISKUSI}

\subsection{Karakterisasi Kandungan Senyawa Kimia Abu Dasar Batubara}

Berdasarkan Tabel 1 terlihat bahwa abu dasar batubara PT PLTU Ombilin, Sawahlunto ini memiliki kandungan yang relatif sama dengan kandungan abu dasar yang digunakan oleh Oktaviani (2015). Hal ini menunjukkan bahwa komponen abu dasar dari PLTU Ombilin, Sawahlunto tidak mengalami perubahan yang signifikan, sehingga jika diperoleh dengan proses yang sama dapat menghasilkan zeolit dengan jenis yang relatif sama. Komposisi kandungan Si : Al pada abu dasar sangat menentukan jenis zeolit sintetis, selain dari metode dan variabel yang digunakan pada proses pembuatan zeolit.

Tabel 1 Komposisi senyawa kimia abu dasar batubara PT PLTU Ombilin, Sawahlunto, Sumatera Barat

\begin{tabular}{cc}
\hline Senyawa & Komposisi (\%) \\
\hline $\mathrm{Al}_{2} \mathrm{O}_{3}$ & 33,172 \\
$\mathrm{SiO}_{2}$ & 57,236 \\
$\mathrm{Fe}_{2} \mathrm{O}_{3}$ & 3,159 \\
$\mathrm{SO}_{3}$ & 1,814 \\
$\mathrm{CaO}$ & 1,744 \\
$\mathrm{~K}_{2} \mathrm{O}$ & 1,583 \\
$\mathrm{P}_{2} \mathrm{O}_{5}$ & 0,511 \\
\hline
\end{tabular}

\subsection{Karakterisasi Morfologi Permukaan}

Struktur permukaan zeolit sintetis dikarakterisasi menggunakan SEM (Scanning Electron Microscopy). Sintesis zeolit yang berasal dari abu dasar batubara yang diberi perlakuan sonikasi yang berbeda memberikan pengaruh terhadap perubahan bentuk permukaan setelah menjadi zeolit. Hasil karakterisasi SEM dapat dilihat pada Gambar 1.

Pengaruh pemberian lama sonikasi pada bentuk permukaan dapat dilihat pada Gambar 1. Hasil karakterisasi SEM menunjukkan adanya pengaruh sonikasi terhadap ukuran partikel. Jika dilihat dari bentuk morfologi permukaan, masing-masing sampel memiliki bentuk yang hampir sama. Secara umum, sampel yang diberikan sonikasi memiliki morfologi yang lebih seragam daripada sampel tanpa pemberian ultrasonik (Gambar 2.a).

Dilihat dari ukuran partikel, sampel tanpa pemberian ultrasonik memiliki ukuran berkisar $(0,89$ - 1,35) $\mu \mathrm{m}$, sampel sonikasi 0,5 jam berkisar $(0,4-1,22) \mu \mathrm{m}$, sampel sonikasi 1 jam berkisar $(0,5-0,8) \mu \mathrm{m}$, sampel sonikasi 1,5 jam berkisar $(0,4-0,52) \mu \mathrm{m}$ dan sampel sonikasi 2 jam berkisar $(0,88-1,51) \mu \mathrm{m}$. Dari segi ukuran partikel, sampel dengan waktu sonikasi 1,5 jam memiliki ukuran rata-rata yang jauh lebih kecil dibandingkan dengan sampel lainnya. Pemberian sonikasi selama 1,5 jam menjadikan zeolit yang dihasilkan memiliki ukuran yang lebih kecil. 


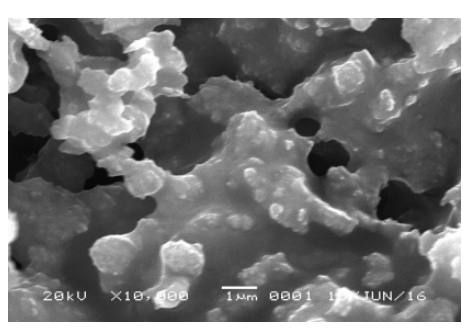

(a)

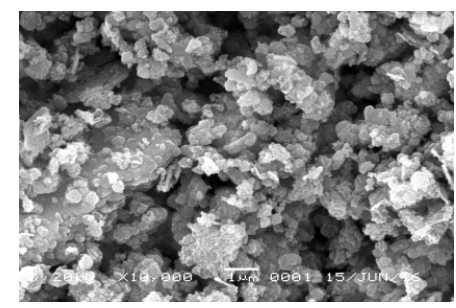

(d)

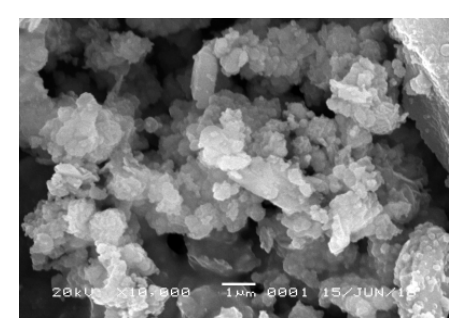

(b)

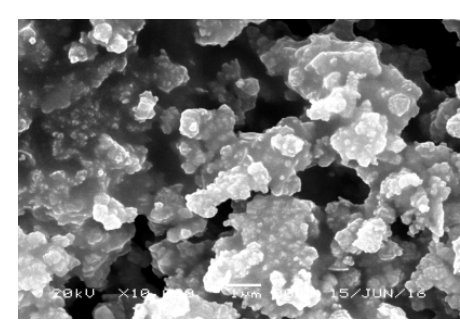

(c)

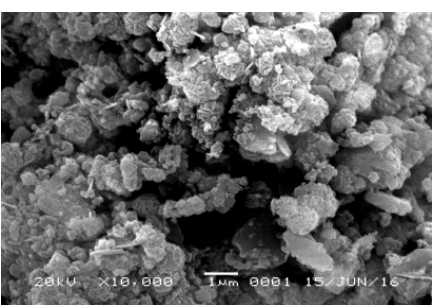

(e)

Gambar 1 Hasil SEM zeolit sintetis (a) tanpa sonikasi (STS), (b) SS 0,5 jam, (c) SS 1 jam, (d) SS 1,5 jam, (e) SS 2 jam

\subsection{Konduktivitas Listrik Zeolit}

Karakterisasi konduktivitas listrik dilakukan dengan menggunakan LCR-meter yang didapat dari pengukuran resistansi masing-masing sampel. Resistansi masing-masing sampel diukur pada frekuensi 100, 120 dan $1000 \mathrm{~Hz}$. Nilai konduktivitas listrik yang didapat berkisar antara $0,05206 \times 10^{-6}-2,1188 \times 10^{-6} \mathrm{~S} / \mathrm{cm}$. Nilai konduktivitas yang didapat berada pada rentang nilai konduktivitas listrik zeolit yaitu $10^{-1}-10^{-11} \mathrm{~S} / \mathrm{cm}$ (Kalogeras, 1998), sebagai nilai konduktivitas pada rentang semikonduktor. Sampel dengan waktu sonikasi 1,5 jam memiliki konduktivitas lebih tinggi daripada sampel lainnya yaitu $2,1188 \times 10^{-6} \mathrm{~S} / \mathrm{cm}$ dengan frekuensi $1000 \mathrm{~Hz}$.

Perubahan nilai konduktivitas listrik terhadap waktu sonikasi dapat dilihat pada Gambar 2. Pada gambar terlihat bahwa waktu sonikasi berpengaruh terhadap nilai konduktivitas listrik dari zeolit sintetis yang dihasilkan.

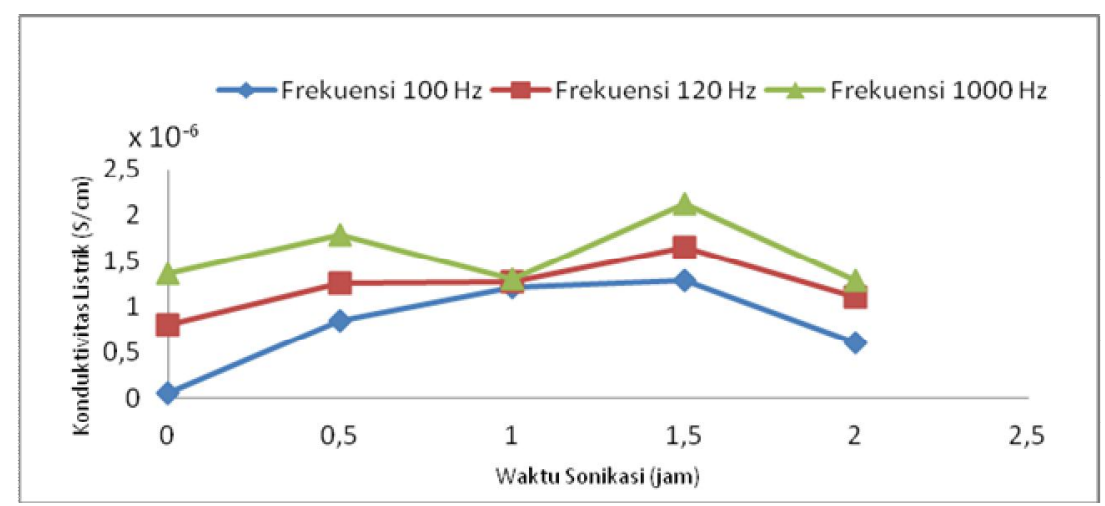

Gambar 2 Grafik hubungan waktu sonikasi terhadap konduktivitas listrik zeolit sintetis pada masing-masing sampel

Jika dibandingkan antara pemberian sonikasi 0,5; 1 dan 2 jam sonikasi, sampel dengan 1,5 jam sonikasi memiliki nilai konduktivitas lebih tinggi dibandingkan sampel lainnya. Pemberian sonikasi pada 1 jam memiliki nilai konduktivitas listrik yang hampir sama terhadap frekuensi, kemungkinan terjadi perubahan struktur pada zeolit yang menyebabkan aktivitas pembawa muatan tidak berpengaruh terlalu besar terhadap frekuensi. Untuk itu perlu dilakukan karakterisasi pada setiap tahap untuk mengetahui lebih jauh proses yang terjadi selama pembuatan zeolit dengan pemberian sonikasi. Gambar 2 menunjukkan bahwa hingga sonikasi 
1,5 jam konduktivitas listrik yang dihasilkan cendrung meningkat kecuali pada frekuensi 1000 Hz. Hal ini dikarenakan dengan lamanya waktu sonikasi yang diberikan menyebabkan meningkatnya mobilitas pembawa muatan yang menyebabkan tingginya nilai konduktivitas listrik yang dihasilkan. Selain itu, nilai konduktivitas listrik juga ditentukan oleh faktor-faktor internal dari sampel zeolit. Faktor internal yang mempengaruhi nilai konduktivitas listrik zeolit sintetis yang dihasilkan diantaranya: jenis pembawa muatan, jumlah pembawa muatan, mobilitas pembawa muatan, kemurnian (kristalinitas), jarak antar atom, luas permukaan dan lain-lain (Smallman dan Bishop, 2000).

Keadaan konduktivitas ini dapat dilihat dengan jelas pada Gambar 2 yang menampilkan kurva perbandingan konduktivitas listrik zeolit terhadap frekuensi. Pada gambar terlihat bahwa konduktivitas zeolit sintetis meningkat dengan semakin besarnya nilai frekuensi pada saat pengukuran. Hasil ini mempunyai kesamaan dengan hasil yang diperoleh oleh Sriwahyuni (2015). Selain tingkat kemurnian zeolit, pengaruh frekuensi pada konduktivitas menunjukkan adanya gejala vibrasi dari atom-atom zeolit yang berkesesuaian dengan frekuensi yang diaplikasikan pada saat proses pengukuran. Vibrasi ini cenderung membuat aktivitas pembawa muatan menjadi meningkat sehingga menjadikan konduktivitas menjadi tinggi (Ibach dan Luth, 1995).

\section{KESIMPULAN}

Pemberian sonikasi pada proses pembuatan zeolit sintetis mempengaruhi morfologi zeolit sintetis yang dihasilkan. Pemberian sonikasi menghasilkan morfologi permukaan yang lebih seragam. Zeolit dengan pemberian waktu sonikasi selama 1,5 jam lebih konduktif listrik dibanding sampel lain dengan nilai konduktivitas $2,1188 \times 10^{-6} \mathrm{~S} / \mathrm{cm}$. Lamanya waktu sonikasi tidak linier terhadap nilai konduktivitas listrik zeolit.

\section{DAFTAR PUSTAKA}

Audy, D., Herling, D, T., 2008, Derajat Kristalisasi sebagai Fungsi Waktu dan Waktu Kristalisasi pada Sintesis Zeolit dengan Gelombang Mikro, Chemistry Program, Vol. 1, No. 1, Jur. Kimia UNSRAT Manado, hal. 19-24.

Azizi, S. N dan Yousefpour, 2010, Journal of Inorganic and General Chemistry, Ultrasonics Sonochemistry, Vol. 636, hal. 886-890.

Ertugrul dan Alime, 2007, Dielectric Behavior of the Catalyst Zeolit Na-Y, Turkis Journal of Chemistry, Tubitak, hal. 523-530.

Fatiha, W. Y., 2013, Sintesis Zeolit dari Fly Ash Batubara Ombilin pada Temperatur Rendah dengan Menggunakan Air Laut, Skripsi, FMIPA UNAND, Padang.

Hamdan, H., 1992, Introduction to Zeolite Synthesis, Characterization and Modification, University Technologi of Malaysia (UTM), Malaysia.

Lestari, T. dan Muttaqin, A., "Pengaruh Air Laut Terhadap Sifat Listrik Zeolit Sintetis Dari Bottom Ash Melalui Proses Alkali Hidrotermal", Jurnal Fisika Unand, Vol. 7, No. 1, Jur. Fisika Unand,,hal. 19-27, 2015.

Nikmah, R, A., 2008, Pengaruh Waktu dan Perbandingan Si/Al terhadap Pembentukan Zeolit A dari Abu Dasar Bebas Karbon dari PLTU PT. IPMOMI dengan Metode Hidrotermal, Jurnal Zeolit Indonesia, Vol. 7, No.1, Jur. Kimia, Institut Teknologi Sepuluh Nopember.

Oktaviani, Y. dan Muttaqin, A., 2015, Pengaruh Temperatur Hidrotermal terhadap Konduktivitas Listrik Zeolit Sintetis dari Abu Dasar Batubara dengan Metode Alkali Hidrotermal, Jurnal Fisika Unand, Vol. 4, No. 4, Jur. Fisika Unand, hal. 358-364.

Smallman, R. E. dan Bishop, R. J., 2000, Metalurgi Fisik Modern dan Rekayasa Material, Edisi Keenam, Erlangga, Jakarta.

Sriwahyuni, N. dan Muttaqin, A., 2015, Pengaruh Temperatur Peleburan Alkali terhadap Konduktivitas Listrik Zeolit dari Bottom ash Batu Bara, Jurnal Fisika Unand, Vol 7, No 1, Jur. Fisika Unand, hal. 19-27.

Suslick, K, S., 1994,The Chemistry of Ultrasound, The Yearbook Of Science \& The Future, Encyclopedia Britanica : Chicago. 